\title{
Legal Mechanisms for Energy Efficiency Adoption in Telecommunications Operations in Nigeria
}

\author{
Kolawole Anthony Fayemi \\ Centre for Petroleum, Energy Economics and Law, University of Ibadan, Oyo State, Nigeria
}

\begin{abstract}
This study reviews the poor adoption of energy efficiency in Nigeria against the backdrop of its enormous socioeconomic benefits globally. The study adopted the exploratory research design. It appraised existing literature to determine the potency of law as a tool for addressing the energy efficiency adoption gap in Nigeria. Law is presented as a veritable tool for the promotion of energy efficiency in Nigeria while the telecommunications sector was chosen as the test environment due to the energy intensity of telecommunications operations. The Social Engineering Theory of Law propounded by Roscoe Pound provided the framework for this study. The study revealed that energy efficiency adoption in Nigeria has been very low, especially in energy intensive sector such as telecommunications. Although there exist policies and plans on energy efficiency adoption in Nigeria, these policies are merely of persuasive authority without any force of law. They are at best statements showing the intention of governments on the subject of energy efficiency. The study therefore recommends the codification of energy efficiency standards and requirements and specifically makes a case for the use of sector specific regulations as an effective means of energy efficiency adoption within the telecommunications sector in Nigeria.
\end{abstract}

Keywords: Energy Efficiency, Legislation, Social Engineering, Telecommunications

DOI: $10.7176 / \mathrm{JLPG} / 81-05$

Publication date: June $30^{\text {th }} 2021$

\subsection{Introduction}

Energy efficiency has caught attention as a significant resource for economic and social development with benefits to several facets of human endeavours beyond the conventional scope of reduced energy demand and lower greenhouse gas emissions. The concept of energy efficiency itself was developed during the first energy crisis in 1973. Lovins ${ }^{1}$ defined the term to mean a system that seeks to achieve the production of economic output through the use of the least possible amount of energy. Simply put this can be expressed as the ratio of economic outputs measured against the corresponding input energy. From the demand-side perspective, the term energy efficiency majorly refers to measuring efficiency at the end-use segment of the value chain of any productive activity and this refers to the proportion of energy used to achieve a particular purpose which is directly beneficial either to the individual personally or for other non-personal purposes which is tangible and measureable. In the context of sustainability and development, energy efficiency has been described as the hidden fuel. ${ }^{2}$ Over time, energy efficiency has moved beyond its traditional connotation of being a reduction in the energy that is required to execute or perform a given service (such as cooling, heating, transportation, lighting etc.) or level of activity through the application of technology to a more conventional status of being the "first fuel". Thus in 2012, the International Energy Association (IEA) in a report ${ }^{3}$ emphasized the benefits of energy efficiency as one that stretches well beyond the simple scaling back of energy demand. The study challenged the assumption that the broader benefits of energy efficiency cannot be quantified and went on to show the potential inherent in energy efficiency to support economic growth, enhance social development, advance environmental sustainability, ensure energy security and help advance social prosperity.

The understanding of the real value of energy efficiency is becoming more important as it continues to gain attention as a vital resource for economic and social development across all economies. The International Energy Association ${ }^{4}$ referred to this as the "multiple benefits of energy efficiency". The IEA study sought to establish the fact that energy efficiency helps to achieve a much broader range of outcomes and can deliver substantial value that will contribute to the human ambition to improve welfare and wealth through a wide range of socioeconomic impacts beyond the traditional understanding of energy efficiency. The multiple benefits approach to energy efficiency would therefore enhance a better understanding of the concept as it redirects the focus on the conventional view of energy efficiency from the limit of just reduction in energy demand to identifying its role

\footnotetext{
1 Lovins, A. (1976). Energy strategy: the road not taken? Foreign Affairs, 55(1), 65-96 55(1). 65-96. [online] Available: https://www.jstor.org/stable/i20039621 (Feb 24, 2021)

${ }^{2}$ Yang. M and Yu. X., (2015). Energy Efficiency, Green Energy and Technology. London: Springer-Verlag. Chapter 2: 11-18

3 International Energy Agency, (2014), Capturing the multiple benefits of energy efficiency, Page 19. [online] Available: https://www.iea.org/reports/multiple-benefits-of-energy-efficiency (Jan 4, 2021)

4 International Energy Association, (2014), Capturing the Multiple Benefits of Energy Efficiency, Page 19. [online] Available: https://www.iea.org/reports/multiple-benefits-of-energy-efficiency (Jan 4, 2021)
} 
in the delivery of concrete social and economic improvements. The implication of this is that energy efficiency has to do with economic efficiency and it encompasses all kind of technological, behavioral and economic changes that decreases the quantity of energy consumed per unit of GDP ${ }^{1}$.

Nigeria sits in the midst of a large and robust energy reserve and is ranked as having the 10th largest oil reserve in the world estimated at about 25billion barrels and a massive natural gas reserve of more than 166 TSCF (Trillion Standard Cubic Feet) ${ }^{2}$, yet the country has been confronted with acute energy challenges and successive governments have achieved very little in producing a lasting solution. Nigeria has invested enormously towards the provision of energy infrastructure coupled with its vast endowment in energy resource, yet the output of its power sector when compared to other developing economies can at best be described as poor. The incident of energy wastage in Nigeria is underscored by the fact that households and businesses utilize more energy compared to what they actually need. Uyigue et $\mathrm{al}^{3}$ in his community based study which is aimed at examining commercially and behaviourally low-cost ways of reducing energy consumption in the residential, public and private sectors in Nigeria identified some gaps with respect to energy utilization in Nigeria as follows:

i. Dominant use of incandescent light bulbs

ii. Use of light bulbs for advertisement of goods

iii. Use of outdoor lighting during the day

iv. Undertaking industrial activities in residential areas

v. Keeping appliances on standby mode

vi. Simultaneous use of multiple appliances in public buildings

vii. Keeping home appliances plugged to power when not in actual use

viii. Attachment to used electrical appliances

ix. Use of Inefficient heating equipment

Notwithstanding the enormous benefits of energy efficiency, its adoption has been very low in Nigeria. According to $\mathrm{Alan}^{4}$, despite all of the benefits derivable from energy efficiency, it is yet to receive a commensurate measure of acceptance and this, he identified to be as a result of the misconception that energy efficiency is considered expensive. He argued that, energy efficiency is more of an investment and not an expense. Investments are made in the present just in the same manner as stock or a bond, with an expectation to reap returns or dividends in the near future. The same way investment in a business venture will require upfront cost is the same way energy efficiency will require financial outlay and that is the basis for the misconception that energy efficiency is expensive. However, to the contrary, energy efficiency investment will usually yield a return on investment such that the amount of money saved on electricity and energy bills is often far greater than the initial capital investment in the long-term.

There exist huge opportunities for accelerated socio-economic development that is laying waste as Nigeria continues to lag behind in energy efficiency adoption. Law can serve as a major tool for closing this gap significantly. This position is anchored on Roscoe Pound's theory of law as an instrument of social engineering. The key ideas propagated by the sociological school of jurisprudence include the ideas that law is not a unique study of life but only one of the tools for social control"5 The study shall examine various approaches through which Law can be used to promote the adoption of energy efficiency in Nigeria.

\section{Aim, Scope and Methodology}

Although various studies have been conducted on the multidimensional benefits of energy efficiency, however, this work will focus on examining the theoretical perspectives for using law as a tool to deliver these benefits in Nigeria, using the telecoms industry as a case study. It is important to note that the details of each system of law, the particular energy efficiency benefits they will deliver and the macro-economic effects were not examined and are outside the scope of this work.

The study adopted the doctrinal research design. It utilized literature searches, appraisals of existing literature and review of relevant statute books, legislations and government policy documents. Of particular importance and focus here are enabling laws and regulations of key regulatory institutions of government whose statutory functions have a direct bearing on the study. Additional data and information were collected from other

\footnotetext{
World Energy Council, (2010), Energy Efficiency; A Recipe for Success, Page 5. [online] Available: https://www.worldenergy.org/publications/entry/energy-efficiency-a-recipe-for-success (Feb 25, 2021)

${ }^{2}$ Crude Oil Reserve/Production Page of the National Petroleum Investment Management Services (NAPIMS) website. [online] Available: http://www.napims.com/crudeoil.html. (Feb. 29, 2021)

${ }^{3}$ Uyigue, E. (2009). Energy efficiency survey in Nigeria: a guide for developing policy and legislation. Community Research and Development Centre. Benin City. [online] Available: http://www.credcentre.org/Publications/EE\%20Survey\%20Nigeria.pdf (March 24, 2021) ${ }^{4}$ Alan, P. (2004). Energy Efficiency-Its Potential: Some perspectives and Experiences. Background paper for International Energy Agency Energy Efficiency Workshop, Paris. [online] Available: https://citeseerx.ist.psu.edu/viewdoc/download?doi=10.1.1.567.5304\&rep=rep1\&type=pdf (April 24, 2021)

5 Etudaiye, M.A. (2012). The Relevance of the Sociological School of Jurisprudence to Legal Studies in Nigeria. [online] Available: https://www.academia.edu/4167468/THE relevance of the sociological school of jurisprudence to legal studies in nigeria (Mar. 22, 2021)
} 
research works on the subject matter as contained in books, standard journals, articles, seminar papers, statistical abstracts, conference proceedings, magazines and newspapers. Case laws such as decisions of superior courts of records, were also consulted in this regard. The literature reviewed for this study were content analyzed through the documentary observation technique. The content analysis afforded the opportunity to review commentaries which were extracted from the text of the secondary sources. The documentary observation technique was adopted due to its effectiveness in data gathering where it is impractical or difficult to conduct interviews or have direct observations with respondents. This helped to present the information that cannot be manipulated. The stated methods helped to reach conclusive findings with no negative impacts on the safety of the study.

\section{Results and Discussions}

Roscoe Pound's theory of law as an instrument of social engineering provides the theoretical basis for this study. Roscoe Pound advocated for an inter-disciplinary approach to the understanding of the concept of law. He disregarded the abstract application of law and rather conceived law as a means for achieving social control. According to Pound, the task of the lawyer is likened to that of an engineer who is saddled with building an efficient structure for society by seeking to satisfy the maximum amounts of wants the with the minimum amounts of friction thereby achieving a balance between conflicting social interests ${ }^{1} \mathrm{He}$ highlighted several interests which the law should pursue in order to protect the society and categorized these into individual, public and social interests. This is the justification of law as being capable to regulate and standardize the society as well as control its impacts and does this via several means. On the one hand, law is prescriptive and functions normally with the force of sanctions or by incentivizing a specific act or conduct, albeit with the might of the State. On the other hand, validity or legality of an act as against the other can be conferred by law. These characteristics invest the law with the capacity to produce expected social outcomes. This is the underlying principle upon which this work proceeds to argue that law can therefore be a veritable vehicle through which energy efficiency can be integrated into the fabrics of the Nigerian socio-economic system.

\section{Law and Energy Efficiency Adoption in Nigeria}

Society is dynamic and continues to evolve as social actors interacts and struggle for survival. Every society is defined by various contentions between its social actors as a results of the peculiar interests that resides therein whether personal or social interests. Thus as society evolves the law that governs the conducts and affairs of the social actors must progressively evolve to deal with the social realities as they come to the fore. For instance, the advent of the internet, growth of ICT and social media has significantly altered the features of social interaction from the way it was 20years ago. Therefore, with these new realities came new social problems that never existed in the old social order such as trans-border crimes, data sovereignty, privacy and data protection, cyberattacks and cyber bullying, online pornography, terrorism and radicalism, electronic fraud, cyber security, selfesteem issues in teenagers, loss of cultural identity etc. Leveraging on the engineering value of law as expounded by Roscoe Pound, there is a need to update existing laws to catch up with social realities, where there exists an evolving subject matters, there is a need for the legislators to urgently make laws for the regulation of those aspects of social life. In terms of our present study, the latter context is required as there is a need for codification of legislations specifically for energy efficiency adoption in Nigeria. Countries that have reaped the gains of energy efficiency have done so through the instrument of legislations with national application and relevance. Germany ${ }^{2}$ and Japan ${ }^{3}$ and even Nigeria's West African neighbor, Ghana ${ }^{4}$ are worthy examples in this regard.

The second leg of this call for codification of energy efficiency legislation is to explore the option of sector specific legislations in the form of energy efficiency regulations made pursuant to primary legislations that governs various sector of the economy especially energy intensive sectors such as telecoms, manufacturing, transportation etc. The most recent experience for energy efficiency adoption in Nigeria by the government has been the introduction of The National Energy Efficiency Action Plan (NEEAP) ${ }^{5}$ which was developed by the Ministry of Power in conjunction with the ECOWAS Centre for Renewable Energy and Energy Efficiency (ECREEE) and approved on July 14, 2016 by the National Council of Power (NACOP). The NEEAP was developed as a road map for moving Nigeria towards energy efficiency as part of the prescription under the National Renewable Energy and Energy Efficiency Policy (NREEEP) which directs the Hon. Minister of Power

\footnotetext{
${ }^{1}$ Pound, R. (1946). Interpretations of Legal History. 156. Harvard University Press.

${ }^{2}$ From ideas to laws - how Energiewende policy is shaped. [online] Available: https://www.cleanenergywire.org/factsheets/ideas-laws-howenergiewende-policy-shaped (April 12, 2021)

${ }^{3}$ Kimora., O. (2010). Japanese Top Runner Approach for Energy Efficiency Standards. SERC discussion paper: SERC09035. [online] Available: https://criepi.denken.or.jp/jp/serc/research_re/download/09035dp.pdf (May 8, 2021)

${ }^{4}$ Edjekumhene., I. A. M. and Brew-Hammond. A. (2001). Power Sector Reform in Ghana: The Untold Story. Kumasi Institute of Technology and Environment. [online] Available: http://pdf.wri.org/power_politics/ghana.pdf. (April 27, 2021)

5 National Energy Efficiency Action Plan, Available:

http://www.power.gov.ng/Press\%20Release/NATIONAL\%20ENERGY\%20EFFICIENCY\%20ACTION\%20PLANS.pdf (April 12 2021)
} 
to develop the NEEAP within 6-12 months of the approval of NREEEP, in line with the intention of the government to achieve an electricity vision of attaining 30,000MW of power by the year 2030 with at least $30 \%$ renewable energy in the electricity mix (Electricity Vision 30:30:30) which is vigorously pursued in a threeprong stages of attaining stable, sustainable and then uninterrupted power supply in Nigeria. ${ }^{1}$ Under the NEEAP, energy efficiency targets and trajectories for the year 2020 includes the use of efficient lighting by $40 \%$ of the households, increase in efficient energy with at least $20 \%$ when compared to the baseline in high-energy consuming sectors, achievement of $10 \%$ biofuel blends, improvement in the efficiency of the bioenergy sector, reduction in distribution loss to $15-20 \%$ target. Furthermore, the plan projects that by 2030 , almost $100 \%$ of the households will be making use of efficient lighting, efficient energy usage in high-energy consuming sectors will have increased by at least 50\% in comparison to the baseline, firewood demand will have been curbed below the supply capacity, reduction in distribution loss to less than $10 \%$ target

A review of the implementation of the NAEEP vis-à-vis its targets, particularly in 2020, shows that the NEEAP attempted to capture various sectors of the Nigerian economy where potentials exists for the integration of energy efficiency and developed energy efficiency targets on five broad categories of; lightning, high performance distribution of electricity, standards and label, buildings and industries and in terms of implementation, the NEEAP recognizes the role of some national public institutions which include National Environmental Standard Regulation Enforcement Agency (NESREA), the Federal Ministry of Environment, Ministry of Power, Federal Ministry of Lands, Housing and Urban Development, Standard Organization of Nigeria, Federal Ministry of Industry, Trade and Investment (FMITI), Small and Medium Enterprises Development Agency of Nigeria (SMEDAN), National Association of Chambers of Commerce, Industry, Mines and Agriculture (NACCIMA) and the Nigerian Customs Services.

The challenge with this approach that has been adopted by the government is that the NEEAP itself is not a legislation and as such it does not have the force of law. It is a policy document, which at best is persuasive in nature as an expression of the intention or plan of government on a particular subject matter. We shall now discuss some legal mechanisms which can be employed for the integration of energy efficiency in the telecommunications sector via the instrumentality of law. Majority of these ideas are strictly legal while the rest are not totally legal procedures ${ }^{2}$. Nonetheless, the procedures which are not totally legal will be situated within a legal context. Generally, the appropriate application of these procedures will help with the adoption of energy efficiency in the telecommunications sector.

\subsection{Legislation}

Legislation is a written law that is enacted by the organ of government that is constitutionally saddled with legislative functions generally known as the Parliament. In Nigeria this entity may either be the National Assembly at the federal level which is comprised of the Senate - which is the upper legislative branch and then the House of Representatives - which is the lower branch or the Houses of Assembly of the various states of the federation. Legislation is the end product of series of deliberate action of parliament aimed at driving changes in the society. The process of effective law making that will deliver the appropriate results requires inputs of laymen, technical subject matter experts, the academia as well as other experts coupled with those of skilled draftsmen. Legislation is the basis of critical governmental action in different aspects of political, economic and social aspects of national life. Therefore, the starting point in the adoption of energy efficiency in Nigeria is legislation. Laws which have the capacity to drive change are often the outcome of serious and holistic planning that employs a multidisciplinary procedure to law making. Legislation may be primary or secondary. It is primary when it is an enactment by the legislative arm of government at either the federal or state level and it is secondary when it is a legislation made by a person, an institution or entity which is not the parliament itself but who derive its powers from a law made by the parliament. In the case of Barclays Bank of Nigeria Limited $\mathrm{v}$ Alhaji Adam Badejoko Ashiru \& Ors ${ }^{3}$ the Nigerian Supreme Court held that "subordinate legislation is legislation made by a person or body other than the sovereign in Parliament by virtue of powers conferred either by statute or by legislation which is itself made under statutory powers" 4 .

There is a need for a primary legislation on energy efficiency in Nigeria, formulated by the parliament at the national level as well as by the Houses of Assembly of the different states of the federation. The objective and importance of such legislation will be to make energy efficiency adoption an obligation on the part of government and the citizenry as a whole. It will establish a regulatory framework for energy efficiency across all

\footnotetext{
${ }^{1}$ National Energy Efficiency Action Plans, paragraph 3 of page 2.

${ }^{2}$ Kemasuode. W. (2017), Law as an Instrument of Sustainable Change in the 21st Century. Paper delivered by the Attorney General and Commissioner for Justice Bayelsa State at the Law Week opening ceremony of Anaocha Branch of Nigerian Bar Association. [online] Available: $\quad$ https://barristerng.com/nba-anaocha-branch-law-week-law-as-an-instrument-of-sustainable-change-in-the-21 st-century-bykemasuode-wodu/ April 24, 2021

${ }^{3}$ Barclays Bank of Nigeria Limited v Alhaji Adam Badejoko Ashiru \& Ors (1978) 6-7 S.C. 99

${ }^{4}$ Per Idigbe, J.S.C. (P.20, Paras.E-G)
} 
sectors of the economy at both the supply and demand side of the energy chain. Specifically, an energy efficiency law will make provisions for the promotion of energy efficiency in energy generation, transmission, distribution and consumption at the household and industrial segments of the economy. It will also cover sectors such as buildings, transportation, manufacturing, oil and gas operations and telecommunications etc. it will also cover other key issues such as actions and responsibilities of the different tiers of government viz, federal, state and local governments for the achievements of the Country's energy efficiency targets, measures for the development of energy efficiency services market, energy efficiency planning, monitoring and compliance requirements as well as energy efficiency awareness and orientation for the citizenry over a particular of time. All relevant stakeholders must be involved in the process of law making and other support mechanisms that will aid good legislation will be discussed below.

\subsubsection{Subsidiary Legislation}

In terms of hierarchy, next in relevance, scope and importance after primary legislation is subsidiary or delegated legislation which are typically in the form of regulations, rules, bye-laws, guidelines and standards. These are basically enactments made by entities or bodies other than the legislature in accordance with the powers conferred by the enabling legislation. These types of legislations have become very significant because it is practically impossible for the legislature to make laws for every aspect of human life and all socio-economic issues and so the dynamics of law making has evolved in such a way that enabling statutes and legislations confer powers on persons, bodies and institutions to make regulations, guidelines and standards covering specific day-to-day issues that the legislation would not have envisaged or could not cover. A subsidiary legislation that is validly made carries similar effect as the primary legislation. ${ }^{1}$ However, subsidiary legislation is inferior to primary legislation and is limited by the ultra vires doctrine which means exercising authority beyond delegated powers and the doctrine of delegatus non potest delegare which curtails the further delegation of a power that was originally delegated. In the case of A.G Bendel State v A.G. Federation and $22 \mathrm{Ors}^{2}$ the Supreme Court held that "a delegate cannot delegate its functions, unless he is otherwise authorized." The effect of this therefore is that a subsidiary legislation must be exercised within the confines of the authority conferred by the primary legislation which is the enabling statute and any abuse of that power will render the subsidiary legislation so made void. In the context of the present study, subsidiary legislation will be a very useful tool for driving energy efficiency adoption in the Nigerian telecoms sector. Currently, the telecoms sector is one of the highly regulated sectors of the Nigerian economy under the auspices of the Nigerian Communications Commission (NCC).

The NCC is one of the many agencies of government which utilizes subsidiary legislations made pursuant to the powers conferred on it in that behalf by the primary legislation or enabling statutes. The primary legislation for the telecoms sector is the Nigerian Communications Act 2003. The NCC has made various regulations and guidelines to address specific issues pursuant to its functions and powers under the Nigerian Communications Act including but not limited to issues on Competition ${ }^{3}$, Universal Access and Universal Service Provisioning ${ }^{4}$, Equipment Type Approval ${ }^{5}$, Telecommunications Networks Interconnection ${ }^{6}$, Quality of Service $^{7}$, Mobile Number Portability ${ }^{8}$ and Consumer Code of Practice ${ }^{9}$. Furthermore, the NCC has also issued a number of guidelines addressing various issues across different areas of its operations within the telecoms sector which are not expressly covered by the Act and these include the deployment of broadband services on the $5.2 \mathrm{GHz}-5.9 \mathrm{GHz}$ frequency band, deployment of $2.4 \mathrm{GHz}$ ISM Band (WiFi) for telecoms services, dispute resolution, international access and voice over internet protocol, installation of telecommunications masts and towers, provision of internet services, advertisements and promotions, collocation and infrastructure sharing, commercial satellite communications, consultations, procedure for granting approval to disconnect telecommunications operators, short code operation in Nigeria, technical standards for interconnectivity of networks, use of short range devices, type approval, external line plants using copper cables and spectrum trading. ${ }^{10}$ In the same vein, Nigerian Communications Commission as sector regulator for the telecoms industry

\footnotetext{
${ }^{1}$ Trade Bank Plc v Lagos Island Local Government Council, (2003) 3 NWLR (pt 806) 11 at 27

${ }^{2}$ A.G Bendel State v A.G. Federation and 22 others, (1982) 3 NCLR 1 SC

${ }^{3}$ Competition Practices Regulation of 2007, Regulation No. 101, Vol 94, Federal Republic of Nigeria Official Gazette, Government Notice No. 70

${ }^{4}$ Universal Access and Universal Service Regulations of 2007, Regulation No. 55, Vol 94, Federal Republic of Nigeria Official Gazette, Government Notice No. 55

${ }^{5}$ Type Approval Regulations 2008, Regulation No. 67, Vol 95, Federal Republic of Nigeria Official Gazette, Government Notice No. 53

${ }^{6}$ Telecommunications Networks Interconnection Regulations 2007, Regulation No. 19, Vol 33, Federal Republic of Nigeria Official Gazette

${ }^{7}$ Quality of Service Regulations 2013, Regulation No. 21, Vol 100, Federal Republic of Nigeria Official Gazette, Government Notice No. 157

${ }^{8}$ Mobile Number Portability Regulations 2014, Regulation No. 101, Vol 92, Federal Republic of Nigeria Official Gazette, Government Notice No. 237

${ }^{9}$ Consumer Code of Practice Regulations 2007, Regulation No. 87, Vol 94, Federal Republic of Nigeria Official Gazette, Government Notice No. 56

${ }^{10}$ Nigerian Communications Commission webpage [online] Available: https://ncc.gov.ng/licensing-regulatory/legal/guidelines (March 18, 2021).
} 
in line with its powers under the Communications Act can enact a telecom sector specific regulation on energy efficiency in Nigeria for the telecoms sector pursuant to its powers under the Nigeria Communications Act, $2003^{1}$ just in the same manner it developed the Competition Practices Regulation $2007^{2}$ to specifically deal with competition related issues within the telecoms sector.

\subsection{The Law Reform Commission}

This is the agency of Government which is saddled with the responsibility of keeping the legal system under constant review, amendment or interventions to bring the law in tune with social realities as a response to the ever changing nature of society. In Nigeria, this agency is known as National Law Reform Commission and is situated under the office of the Attorney General. The body is a multidisciplinary agency which comprises of professionals in different fields with the ability to interact with the public, institutions and individuals with regards to its objective of constantly bringing the law in tune with social needs and realities. The principal objective of the Nigeria Law Reform Commission (NLRC) is "to take and keep under review all Federal laws with a view to their systematic and progressive development and reform in consonance with the prevailing norms of the Nigerian society including, in particular, the codification of such laws, the elimination of anomalies, the repeal of obsolete, spent and unnecessary enactments, the reduction in number of separate enactments, the reform of procedural laws in consonance with changes in the machinery of the administration of justice and generally, the simplification and modernization of the law"3. A careful look at the objective of the NLRC presupposes the codification of the core doctrine of the sociological school of jurisprudence, especially from the phrase "systematic and progressive development and reform in consonance with the prevailing norms of the Nigerian society". This provides a window of opportunity through which the Nigerian Government can introduce the codification of energy efficiency legislation into Nigeria.

It is worth mentioning that on June 13, 2018 the president of the Federal Republic of Nigeria, Muhammadu Buhari, gave the approval for the Nigerian Law Reform Commission (NLRC) to revise the Laws of the Federation of Nigeria 2004. This approval was made pursuant to the request and recommendation of the Attorney-General of the Federation, Mr. Abubakar Malami (SAN) in this regard in accordance with Section 5(2) (d) of the NLRC Act, Cap, N118, LFN 2004 which mandated the Commission to carry out periodic review of federal laws. According to the NLRC Chairman, Mr. Kefas Magaji:

"the objective of the exercise is to produce a new edition of the Laws of the Federation of Nigeria, which will include revised edition of all extant Acts in Nigeria, particularly all federal enactments (including amendments) made since the last revision exercise (December 31, 2002); all federal enactment omitted in the laws of the Federation of Nigeria 2004 edition and subsidiary instruments made under these enactments. The NLRC chairman also noted that this revision is taking place 17 years after the last exercise which falls below international best practices requirement which stipulates that countries undertake revision of their laws every 10 years. He further noted that country's delay in revising its laws has not only occasioned a "huge gap in the body of laws, it has negatively affected the smooth operation of government's institutions and the effective administration of justice, particularly in terms of awareness, access, implementation, citation, referencing and use of extant laws."

The NLRC may carry out surveys, request for memoranda and also engage professionals in discharging its duties in a bid to generate feedback from the general public on gaps in the legal system. A Law Commission which is fully operational will make sure that the needs of the society is duly responded to by the government and that the process of law making is active and deals with the ever changing feature of the society. Thus in the case of energy efficiency in Nigeria, the law commission may initiate an energy efficiency bill for the Country as a whole as a response to the precarious energy situation in Nigeria. Such a Law will seek to incorporate energy efficiency into the economy at a global scale as a major tool for demand side management of electricity in the Country using the tool of energy efficiency across various sectors of the economy.

\subsection{Law and Policy Roundtables}

This refers to specialized fora where technical discussions take place amongst subject matter experts, industry stakeholders and regulators in reviewing current trends and analyzing challenges and opportunities and as well as benchmarking best practices on specific issues relating to particular sectors of the economy. Policy roundtables are useful for discussing interventions in key sectors such as the telecommunications and the end point of such

\footnotetext{
${ }^{1}$ See Sec 70. Nigerian Communications Act 2003

${ }^{2}$ See note 21 above

${ }^{3}$ Sec. 5(1) Nigeria Law Reform Commission Act. Cap N118 Laws of the Federation of Nigeria 2004

4 Ifeoma. P. (2018), Law Reform Commission Set to Unveil the Laws of the Federation of Nigeria. [online] Available: https://dnllegalandstyle.com/2018/law-reform-commission-set-to-unveil-the-laws-of-the-federation-of-nigeria-2018 (Jan 22, 2021).
} 
fora may be to stir legislative actions to address some of the key decisions reached at those for a. On such occasions, there would be presentation of legislative models from other jurisdictions and the consideration of beneficial experiences from both public and private participants in the sector. A law and policy summit on energy efficiency and standards for the telecoms sector may stimulate thoughts and open a world of possibilities on issues around relevance of energy efficiency to the telecoms sector, environmental and socio-economic impacts of energy efficiency and benefits accruable to relevant stakeholders in the telecoms sector - the operators, government and end-users. Such fora also serve to enlighten stakeholders and provide valuable information on the subject matter under consideration.

\subsection{Standards and Policies}

A minimum level of performance is ensured when standards are in place. An efficient mechanism for quality assurance in service delivery is through the development and enforcement of standards in general and specific service. In addition, international best practices in operations are incorporated by enforcing standards. Also, uniformity in processes and products could be executed through standards. Quality can be guaranteed through properly designed and enforced standards and desired uniformity. Performance and evaluation can be monitored via compliance to designed standards. Another effective procedure to provide guidance for good conduct is policy. Standards and policy may be developed by the Law Commission. Furthermore, a technological approach to finding solutions to problems or systems improvement leads to alignment with modern practices. Technological approach to solving problem or systems improvement often leads to aligning the system to international standards and best practices. Therefore, the integration of energy efficiency technologies and standards in the telecommunications sector in Nigeria will align the sector with international best practices and standards. The instrument in any society that shows the pillars on which the society rest is the law, thus the source and the starting point of social engineering is the law. Law can therefore be used for the delivery of innovation that can benefit the society such as the adoption of energy efficiency legislation and standards in the telecommunications sector. However, using legal options for the delivery of developmental goals requires that the operation of the legal system is efficient. Impediment to effective functioning of the legal system is the inefficiencies in the critical institutions of governance. It is essential that the inefficiency of the regulators that will be acting as the law enforcement agencies be critically reduced so as to make the legal options that have been proposed achieve the desired results.

\section{Findings and Conclusion}

Legislation is a veritable tool for the realization of the enormous benefits of energy efficiency in the telecoms sector in Nigeria through the codification of relevant energy efficiency standards for the telecoms sector. This position is further strengthened by the experience in Countries such as Ghana, Japan and Germany where energy efficiency impacts and gains have been realized and it is for these reasons that the Roscoe Pounds theory of Social Engineering is very relevant to the core of this study. The study found that there exists a general policy framework upon which energy efficiency can find expression in Nigeria and recommends the use of law as a tool for integrating energy efficiency standards and technologies into telecommunication operations in Nigeria to accelerate the nation's drive towards climate change mitigation, carbon emission reduction and sustainable development. Whilst the study acknowledges that it may be difficult to enact a national energy efficiency law in Nigeria due to the cumbersome nature of law making that accompanies the formulation of primary legislation with socio-economic impacts across various sectors of the national economy (as evidenced by the Petroleum Industry Governance Bill which is yet to be signed into law over sixteen (16) years after it was first introduced in the nation's Parliament ${ }^{1}$ ), it is recommended therefore that subsidiary legislation be utilized for driving energy efficiency adoption in the Nigerian telecoms sector in the form of a sector specific energy efficiency regulations.

Currently, the telecoms sector is one of the highly regulated sectors of the Nigerian economy under the auspices of the Nigerian Communications Commission (NCC). The NCC can develop a telecom sector specific regulation on energy efficiency. The benefit of having such a regulation is to quickly open up the telecoms sector to adoption of energy efficiency pending the conclusion of the process of developing a country wide energy efficiency legislation. The preference for this approach is further strengthened by the success recorded in other similar subject matters where sectors specific regulations have been deployed to remarkable success. A good example is in the area of competition law in the telecoms sector. The study found that prior to the recent enactment of the Federal Competition and Consumer Protection $\mathrm{Act}^{2}$, there was no comprehensive competition

\footnotetext{
${ }^{1}$ KPMG Newsletter (2017). [online] Available: https://assets.kpmg/content/dam/kpmg/ng/pdf/tax/ng-kpmg-newsletter-on-the-petroleumindustry-governance-bill.pdf (April 5, 2021)

2 The Act was assented by President Muhammadu Buhari on Feb. 5, 2019. (online) Available: http://www.mondaq.com/Nigeria/x/791502/Securities/The+Federal+Competition+And+Consumer+Protection+Act+2019+Regulatory+Impli cations+For+Merger+Transactions+In+Nigeria and https://sec.gov.ng/notice-on-the-passage-of-the-federal-competition-and-consumerprotection-act/ (March 12, 2021)
} 
law legislation in Nigeria or a specialized competition authority, rather competition law issues were handled by sector regulators who were empowered by their enabling legislations to regulate anti-competition issues in their respective sectors. Examples of these are the Nigerian Communications Commission for the telecommunications sector $^{1}$, the National Electricity Regulatory Commission (NERC) for the power sector ${ }^{2}$ and the Nigerian Civil Aviation Authority (NCAA) ${ }^{3}$ for the aviation sector and the National Insurance Commission of Nigeria (NICON) for the insurance sector ${ }^{4}$. Specifically, the Nigeria Communications Act empowers the Nigeria Communications Commission (NCC) to curb anti-competitive practices in the telecoms sector and give competition law powers to the Nigerian Communications Commission (NCC) as sector regulator. ${ }^{5}$ Pursuant to this power, the NCC formulated the Competition Practices Regulations ${ }^{6}$ which contains extensive provisions on competition issues including but not limited to determination of dominant position, abuse of dominant position, anti-competitive agreements and practices and review of mergers acquisition and take-overs.

Similarly, a sector specific energy efficiency regulation for the telecoms sector will establish mandatory energy efficiency standards in terms of network planning and design, network equipment deployment, applicable routing and network configuration technologies as well as power management technologies. The practical benefits of such a regulation will be to ensure that obsolete and power hungry equipment are eradicated from the telecoms sector, only energy efficient equipment are deployed by network operators, investment in alternative renewable energy sources such as solar and wind energy are promoted, international best practices are encouraged and home grown energy efficient solutions can develop organically from within the sector. Additionally, with such regulation, commitments to the adoption of energy efficiency technologies and practices may be included in conditions for the grant of telecoms licenses and licensees service roll out obligations. It is worth mentioning, that the NCC has an already entrenched process for equipment type approval for all equipment that is to be deployed in the telecoms sector, so while the process of making an energy efficiency specific regulation is on-going, the NCC through the department of Technical Standards and Network Integrity may include energy efficiency considerations as part of its equipment type approval process.

There is a need for the NCC as part of its responsibility as sector regulator for the telecoms industry to formulate a Code of Conduct for Data Centre Energy Efficiency which will embody energy efficiency requirements for the operation of data centres in the Country. This is becoming important as telecoms and ICT services expand and continue to drive the development of the country in the $21^{\text {st }}$ century. However, unlike the experience in the EU where the EU Code of Conduct for Data Centre is voluntary in nature and where participants to the Code do not achieve compliance, there are no penalties incurred and resignation from the scheme can be done at any time; the proposed Code of Conduct for Data Centre Energy Efficiency under the management of the NCC should be mandatory with punitive measures where there are infractions or other noncompliance to the provisions of the Code. This is consistent with other guidelines and regulatory instruments of the NCC. Additionally, the Nigerian legal and regulatory environment is remarkably different from that of the EU and it is the well-considered opinion of this researcher that any legal and regulatory framework for the adoption of energy efficiency in the telecommunications sector has to be mandatory and punitive for it to be effective. The fear of sanction is a major driving force for Compliance with legislations in Nigeria and no other sector exemplifies this more than the telecoms sector. A good example that validates this postulation is seen in the record fine of $\mathrm{N} 330$ Billion handed to MTN by the NCC in 2015 for failing to deactivate 5.2million improperly registered SIM card on its network. ${ }^{7}$ Consequently, in its capacity as sector regulator, the NCC becomes saddled with the responsibility for ensuring adoption and integration of energy efficiency in the telecommunication sector, through the instrumentality of law by leveraging the social engineering function of law for this purpose.

\section{Bibliography}

A.G Bendel State v A.G. Federation and 22 others. (1982) 3 NCLR 1 SC

Amaefule, E. Punch Newspaper. [online] Available: https://punchng.com/sim-registration-mtn-pays-n110bn-infine/ (March 24, 2021)

Alan, P. (2004). Energy Efficiency-Its Potential: Some perspectives and Experiences. Background paper for International Energy Agency Energy Efficiency Workshop, Paris. [online] Available: https://citeseerx.ist.psu.edu/viewdoc/download?doi=10.1.1.567.5304\&rep=rep1\&type=pdf (April 24, 2021) Barclays Bank of Nigeria Limited v Alhaji Adam Badejoko Ashiru \& Ors (1978) 6-7 S.C. 99

\footnotetext{
${ }^{1}$ See Sections 4(1), 90, 91, 92 and 93 of the Nigerian Communications Act 2003

2 Section 82 of the Electric Power Sector Reform Act 2005

${ }^{3}$ Section 30(4) (g) \& (i) of the Civil Aviation Act of 2006,

${ }^{4}$ Section 30 of the Insurance Act Insurance Act CAP I17, Laws of the Federation of Nigeria, 2004.

${ }^{5} \mathrm{Sec}$ 4(1) and Secs 90-93 of the Nigerian Communications Act 2003.

${ }^{6}$ Regulation No. 101, Vol 94, Federal Republic of Nigeria Official Gazette, Government Notice No. 70

${ }^{7}$ Amaefule, E. Punch Newspaper. [online] Available: https://punchng.com/sim-registration-mtn-pays-n110bn-in-fine/ (March 24, 2021)
} 
Civil Aviation Act of 2006,

Competition Practices Regulation of 2007, Regulation No. 101, Vol 94, Federal Republic of Nigeria Official Gazette, Government Notice No. 70

Consumer Code of Practice Regulations 2007, Regulation No. 87, Vol 94, Federal Republic of Nigeria Official Gazette, Government Notice No. 56

Crude Oil Reserve/Production Page of the National Petroleum Investment Management Services (NAPIMS) web-site. [online] Available: http://www.napims.com/crudeoil.html. (Feb. 29, 2021)

Edjekumhene., I. A. M. and Brew-Hammond. A. (2001). Power Sector Reform in Ghana: The Untold Story. Kumasi Institute of Technology and Environment. [online] Available: http://pdf.wri.org/power_politics/ghana.pdf. (April 27, 2021)

Electric Power Sector Reform Act 2005

Etudaiye, M.A. (2012). The Relevance of the Sociological School of Jurisprudence to Legal Studies in Nigeria. [online] Available: https://www.academia.edu/4167468/THE_relevance_of_the_sociological_school_of jurisprudence_to_lega 1_studies_in_nigeria (Mar. 22, 2021)

From ideas to laws - how Energiewende policy is shaped. [online] Available: https://www.cleanenergywire.org/factsheets/ideas-laws-how-energiewende-policy-shaped (April 12, 2021)

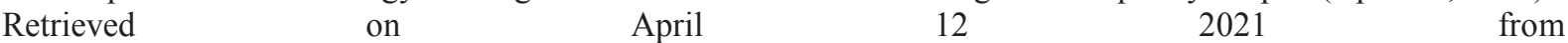
http://www.power.gov.ng/Press\%20Release/NATIONAL\%20ENERGY\%20EFFICIENCY\%20ACTION\% 20PLANS.pdf

Ifeoma. P. (2018), Law Reform Commission Set to Unveil the Laws of the Federation of Nigeria. [online] Available: $\quad$ https://dnllegalandstyle.com/2018/law-reform-commission-set-to-unveil-the-laws-of-thefederation-of-nigeria-2018 ( $\operatorname{Jan} 22,2021)$.

International Energy Agency, (2014), Capturing the multiple benefits of energy efficiency, Page 19. [online] Available: https://www.iea.org/reports/multiple-benefits-of-energy-efficiency (Jan 4, 2021)

Insurance Act CAP I17, Laws of the Federation of Nigeria, 2004.

Kemasuode. W. (2017), Law as an Instrument of Sustainable Change in the 21st Century. Paper delivered by the At-torney General and Commissioner for Justice Bayelsa State at the Law Week opening ceremony of Anaocha Branch of Nigerian Bar Association. [online] Available: https://barristerng.com/nba-anaochabranch-law-week-law-as-an-instrument-of-sustainable-change-in-the-21st-century-by-kemasuode-wodu/ (April 24, 2021)

Kimora., O. (2010). Japanese Top Runner Approach for Energy Efficiency Standards. SERC discussion paper: SERC09035. [online] Available: https://criepi.denken.or.jp/jp/serc/research_re/download/09035dp.pdf (May 8, 2021)

KPMG Newsletter (2017). [online] Available: https://assets.kpmg/content/dam/kpmg/ng/pdf/tax/ng-kpmgnewsletter-on-the-petroleum-industry-governance-bill.pdf (April 5, 2021)

Mobile Number Portability Regulations 2014, Regulation No. 101, Vol 92, Federal Republic of Nigeria Official Gazette, Government Notice No. 237

National Energy Action Plan, [online] Available: http://www.power.gov.ng/Press\%20Release/NATIONAL\%20ENERGY\%20EFFICIENCY\%20ACTION\% 20PLANS.pdf (April 12 2021)

Nigeria Law Reform Commission Act. Cap N118, Laws of the Federation of Nigeria 2004

Nigerian Communications Commission webpage [online] Available: https://ncc.gov.ng/licensingregulatory/legal/guidelines (March 18, 2021).

Pound, R. (1946). Interpretations of Legal History. 156. Harvard University Press.

Quality of Service Regulations 2013, Regulation No. 21, Vol 100, Federal Republic of Nigeria Official Gazette, Government Notice No. 157

Telecommunications Networks Interconnection Regulations 2007, Regulation No. 19, Vol 33, Federal Republic of Nigeria Official Gazette

Trade Bank Plc v Lagos Island Local Government Council (2003) 3 NWLR (pt 806) 11 at 27

Type Approval Regulations 2008, Regulation No. 67, Vol 95, Federal Republic of Nigeria Official Gazette, Government Notice No. 53

Universal Access and Universal Service Regulations of 2007, Regulation No. 55, Vol 94, Federal Republic of Nigeria Official Gazette, Government Notice No. 55

Uyigue, E. (2009). Energy efficiency survey in Nigeria: a guide for developing policy and legislation. Community Research and Development Centre. Benin City. [online] Available: http://www.credcentre.org/Publications/EE\%20Survey\%20Nigeria.pdf (March 24, 2021)

World Energy Council, (2010), Energy Efficiency; A Recipe for Success, Page 5. [online] Available: https://www.worldenergy.org/publications/entry/energy-efficiency-a-recipe-for-success (Feb 25, 2021) 
Yang. M and Yu. X., (2015). Energy Efficiency, Green Energy and Technology. London: Springer-Verlag. Chapter 2: 11-18 